\title{
REPAYMENT PLAN AS ESSENTIAL INSTRUMENT IN PERSONAL BANKRUPTCY IN THE CZECH REPUBLIC
}

\author{
Monika RANDÁKOVÁ2 \\ University of Economics Prague, Department of Financial Accounting and Auditing \\ Jiřina BOKŠOV $\dot{A}^{3}$ \\ ŠKODA AUTO UNIVERSITY, Department of Financial and Managerial Accounting
}

\begin{abstract}
It is possible to undergo a personal bankruptcy in the Czech Republic since 2008. The number of personal bankruptcies has been steadily rising in the country since the arrival of economic crisis in 2009. Because of that it is necessary to examine individuals who had undergone personal bankruptcy and by whom has been the process of personal bankruptcy already completed. Submitted research concerns debt relief of individuals who applied for personal bankruptcy in the time period between 1.1.2008 and 31.12.2011 and whose process of personal bankruptcy was declared as successfully completed until the first quarter of 2015. Until the end of the research this applied to 1.352 individuals. The main aim of the research was to find out the percentage of debt repaid to creditors by each individual with regard to their age. The research has been focused on dividing the sample of 1.352 individuals to different categories according to their age, source of their income and amount of their income. Particular debtors who applied for a personal bankruptcy, have been divided into four age groups. Each individual was afterwards analysed for the source of their income, from which the debts were repaid. Possible sources of income were divided into eleven groups. The researched sample of individuals was consequently divided according to the overall amount of their debt into five categories.
\end{abstract}

\section{KEY WORDS}

Personal bankruptcy, debt relief, debtor, creditor, repayment plan, amount of debt, claim of creditor.

\section{JEL CLASSIFICATION}

[K35, K36]

\footnotetext{
${ }^{2}$ Correspondence address: Monika Randáková, Ing., Ph.D., randakm@vse.cz, University of Economics Prague, Department of Financial Accounting and Auditing, W. Churchill Square 4, 13067 Prague 3, Czech Republic, www.vse.cz

${ }^{3}$ Correspondence address: Jiřina Bokšová, doc., Ing., Ph.D., jirina.boksova@savs.cz, ŠKODA AUTO UNIVERSITY, Department of Financial and Managerial Accounting, Na Karmeli 1457, 29301 Mladá Boleslav, Czech Republic, www.savs.cz
} 


\section{INTRODUCTION}

Personal bankruptcy - debt relief is a legal process giving individuals an opportunity to resolve their complicated financial situation. These individuals, having debts toward multiple creditors, are not able to repay them all. The legal process in the Czech Republic enables to solve the insolvency of an individual via declaration of the personal bankruptcy. There are conditions that must be met to declare personal bankruptcy. The debtor must be indebted to more than just one creditor and be able to repay at least $30 \%$ of its debt, meaning $30 \%$ of the overall amount of debts toward reported creditors. If the personal bankruptcy is resolved through a repayment plan, there is a period of 60 months during which most debtors live only with the minimum income needed for subsistence in the Czech Republic. The amount of income that exceeds this subsistence minimum is used to repay the debts.

The Insolvency Act (Act no. 182/2006 Coll., on bankruptcy and its solution) entered into force on $1^{\text {st }}$ January 2008 . Insolvency proceedings can be divided into two phases. The first phase is the time which precedes the decision on bankruptcy, which is same for all methods of dealing with bankruptcy. The decision on bankruptcy is followed by determination how to solve it and application of chosen method. The Insolvency Act regulates in detail various solutions. (Maršíková, 2014)

The paper shows analyses of 1352 debtors who submitted a proposal for debt relief between years 2008 and 2011. These debtors had reported total debt of almost 800 mil CZK and only twelve of 1352 debtors did not resolved their bankruptcy through a repayment plan. Paper also presents age structure of debtors and type of their debt as well as rate of satisfied creditors.

\section{LITERATURE REVIEW}

The general research related to over-indebtedness and debt relief has been well covered in the articles such as 'The relation between indebtedness of the government, public sector and households in the Czech Republic' (Smrčka, 2011) or 'Predicting bankruptcy with the use of macroeconomics variables’ (Korol \& Korodi, 2010) which deals with the theory of bankruptcies.

\section{Bankruptcy of the debtor and solutions}

Insolvency Act can thus be used in the situation that the debtor is insolvent. The law distinguishes two types of bankruptcy - insolvency and over-indebtedness. Both types include multiplicity of creditors as an assumption. This means that the debtor must have 2 or more creditors to be regarded as a debtor in bankruptcy. While insolvency may occur in all subjects, regardless of whether they are individuals or corporations, entrepreneur or non-entrepreneur, over-indebtedness may occur only on entrepreneurs.

Insolvency is the situation where the debtor has a financial debt more than 30 days overdue and is unable to repay these debts to creditors. Inability to repay the debt must be objective, therefore unwillingness of debtor to repay its debts is not a good enough reason for debt relief. All the above conditions must be met for decision on bankruptcy. The debtor may also became insolvent by the fraud of a third party. However, if it is proven that the debtor is not capable of solving this situation within 3 months after the maturity of its financial debts, the debtor will be deemed as insolvent. Although the law aims at debts more than thirty days overdue, which is necessary for the determination of insolvency, bankruptcy is a lengthy process. (Hásová \& Moravec, 2013) 
The bankruptcy due to over-indebtedness can only occur in entrepreneurs, individuals and corporations. Like insolvent, and there is a condition multiplicity of creditors. The overindebtedness is situation where the debtor's liabilities exceed the sum of all his assets. If it is possible to assume that the debtor will continue with his business in the future, sum of his assets with respect this fact. In connection with the definition of insolvency and its forms it is still important to define the impending bankruptcy. Impending bankruptcy may claim only the debtor where according to all circumstances it is possible to assume that he will not be able to properly and timely perform a substantial part of his liabilities. Debtors who are thus able to predict his future insolvency may claim insolvency process sooner and start to solve their situation in a more convenient time. Unfortunately, experience shows that such debtors are not many. The data in the insolvency register indicates that the vast majority of creditors solve their insolvency until the moment actually occurred.

The Insolvency Act defines three ways of dealing with bankruptcy. They include bankruptcy, reorganization and debt relief. While bankruptcy and reorganization are offered as a possibility of dealing with bankruptcy only for entrepreneurs (bankruptcy in some cases even for nonentrepreneurs), on the other hand, debt relief is the only way of insolvency for non-entrepreneurs (especially individuals).

\section{Debt relief individuals}

Debt relief (personal bankruptcy) which can be even requested by the debtor itself and often is basically the only way the non-business subjects can solve their bankruptcy. (Smrčka, 2011). Personal bankruptcy should help debtors get back to "normal" life as unencumbered citizens and continue with a "clean shield". The point of debt relief is that the debtor will repay its unsecured creditors at least $30 \%$ of debts and the remaining debts will be forgiven him. Whether it is the "right" to forgive the rest of the debts can be discussed. On the one hand, it may seem that the forgiveness of most of the debts is sometimes unfair to properly repaying citizens, however, it is useful to consider how debtor got into a situation in which they find themselves and have no choice but to deal with their situation with personal bankruptcy - how significant can be an impact of individual's social capital on the probability of bankruptcy was clearly demonstrated by authors such as Agrawal at al. (2010) or Stumm at al. (2012) who researched this problem in Great Britain and also focused on the numerous psychological aspects related to the personal bankruptcy. And there is also a study in Canada that has found a correlation between personal bankruptcies and debtor's Health. There is grooving number of acute myocardial infarction (better known as heart attack) among those undergoing debt relief. (Savu, 2016) Within the Czech Republic were psychological and socio-economic reasons for the emergence of personal bankruptcies researched by the Tučková \& Strouhal (2010).

However, it is also necessary to put yourself in the situation of creditors. On the contrary, they strive to make the amount they receive, as high as possible, ideally one hundred percent of their financial claims. This is not surprising when we consider how negatively bankruptcy can affect all proprietors of firms, banks and other creditors (Bonaci \& Strouhal, 2011; Strouhal et al., 2011). To protect themselves from the growing number of personal bankruptcies and losses arising from them, a personal bankruptcy prediction system gained huge importance in last couple of years in banks. Credit card data mining with the purpose of identifying behavior leading to bankruptcy among clients is one of personal bankruptcy prediction. (Xiong, 2013)

Debt relief can be accomplished in two forms - a repayment plan or the monetizing of assets. If the debtor fails to comply with conditions of personal bankruptcy with repayment plan, its situation will be solved by monetizing its assets. In this case, all his assets will be sold and after it is sold, there is no forgiveness of the remaining part of the debts. In the interest of all debtors should therefore be 
made to comply with the conditions laid down by the insolvency court and avoid bankruptcy option. Additionally, the fact that the laws and procedures linked with the personal and company bankruptcies represent a fundamental part of the legal environment of market societies was clearly demonstrated by the Di Martino (2005).

The most common debtors who undergo the process of debt relief are consumers, meaning individuals who are non-entrepreneurs. The meaning of this term, non-entrepreneur debtor, has its history. The primary case law had implied that the debtor cannot be an entrepreneur from the view of legal enactment, meaning that they do not have trade licence or they have it stopped, and that they do not have debts coming out of their business. By this it is meant debts from their business activities on its own and also debts which did not come out of their business activities but has originated from business activities of others (e.g. taking over guarantees for a debt which has come out of business activities). As the time went, the strict explanation of this term has eased and sole possession of trade licence is no more a reason to refuse someone's debt relief proposal and it is also possible for the debtor to have some liabilities from their business activities. In the latter it is necessary to obtain the agreement of creditors which declares that it is possible to repay the business debts through debt relief. According to the current case law it is even possible for the debtor to start a business if they lose their job position while undergoing the process of debt relief (Resolution of the High Court in Prague, 2010). Current state is a big benefit for the creditors because it allows the debtor to raise their income which leads to higher and faster satisfactions of their receivables. On the other side it is forbidden for the debtor to take on new debts in case of fulfilling the repayment plan if there is any risk that the debtor is not going to be able to repay them when they are due. However being an entrepreneur involves this risk. It is up to the decision of the creditors and the court. (Maršíková, 2014)

\section{Creditor's Demands}

Creditors who are applying their claim against the debtor are participants in the insolvency process. In the case of creditors there are no limits. Among them can be entrepreneurs, non-entrepreneurs, individuals and other legal entities however they need to apply their claim against the debtor. It is possible to divide the creditors into different categories. One of them is the amount of time, for which they attend the process. These can be either creditors who claim their rights through entered receivable who then attend the whole process, or other creditors who take part only in a part of the insolvency process, in which their receivable is involved. The latter could be for example claims against the estate and their equivalent departments. Another difference is between secured and unsecured creditors. A secured creditor is an entity which receivable is secured by equity that belongs to the assets of the debtor either by lien, right of retention, limitation of transferring the property, reinsurance transfer of right or assignment of claims. Their advantage in comparison to unsecured creditors is their better position in the insolvency process. That means that their receivables will be satisfied via selling the assets of the debtor, by which the receivable is secured. As a particular example, may serve a receivable from a mortgage bank, which is secured by a family house of the debtor. In case the debtor does not repay their debt according to the contract, the house would be sold and the receivable of the bank would be satisfied. Unsecured creditors are satisfied either from the sold assets of the debtor (fulfilment of the debt relief via selling debtors assets) or from their incomes in the following five years (fulfilment of the debt relief via repayment plan).

In case of debt relief the creditors take part in deciding which kind of debt relief the debtor will undergo, they oversee the activity of bankruptcy administrator and at the same time they can influence the actual selection of the bankruptcy administrator. Secured creditors are also entitled to give instructions to the bankruptcy administrator how to treat the assets of the debtor which are 
securing their receivables. All creditors realize their right through the creditor bodies which are Meetings of Creditors and Board of Creditors.

Application for a debt relief can be brought in only by the debtor and through the application the debtor proposes the way of how their personal bankruptcy is going to be handled. The application can be applied with the insolvency application or after the start of the insolvency process. For the court to be able to approve of debt relief, the application must be handed in. If this does not happen, the court decides to deal with the insolvency through distrainment of their assets and income and not by debt relief.

\section{The Way of Undergoing the Process of Personal Bankruptcy}

Debt relief can be dealt with either by repaying the debt according to the repayment plan or by monetisation of the debtor's assets. It is also possible to combine both methods. The debtor must propose the combination of both methods and agree to it (ergo the court cannot instruct the debtor to do so). The advantage of the combination is higher satisfaction of creditors. About the way of undergoing the bankruptcy is decided on the Meeting of Creditors by creditors themselves. The debtor is obliged to attend this meeting in order to answer all eventual questions and convince the creditors that he is able to fulfil the debt relief plan. The voting right is assigned only to unsecured creditors who applied with their receivables in the insolvency process. Secured creditors do not vote on this matter for a simple reason - they will be satisfied from the selling of the assets. The way of debt relief is accepted if more than a half majority has voted in favour of it (the votes are in this case also counted according to the amounts of the receivables). During the decision-making and voting the creditors have at their disposal information about the debtor and the bankruptcy administrator. This information consists of income of the debtor in the past five years and his current assets. Because of that they have enough information in order to be able to decide which way of the debt relief is more preferable for them. In real life the repaying through a repayment plan is a lot more common. The accepted debt relief confirmed by the court is obligatory for both the debtor and all the creditors regardless the way for which they voted.

The statistical data imply that opportunity of declaring personal bankruptcy is being used by more and more people. It is evident that the number of insolvency applications corresponds to the unemployment rate. Whether the number of applications corresponds also to the e.g. age, gender or amount of income of the debtors will be shown by the research of individuals who applied for personal bankruptcy in the Czech Republic during the period between 1.1.2008 - 31.12.2011 and by whom was the debt relief successfully finished in the first quarter of the year 2015 .

\section{METHODOLOGY}

\section{Aim of research}

The institute of personal bankruptcies was introduced into The Czech law on January 1st, 2008. The main aim of research was to find out the rate of satisfaction of debtors - individual natural persons who successfully went through the process of personal bankruptcy in Czech Republic. Before defining these aims this research took into account previously conducted studies within this field, such as, Carter \& Van Auken (2006) which focused on insolvencies particularly within the small firms and Pasekova \& Bařinova (2013) which researched the problem of personal bankruptcy in the Moravian-Silesian region (Czech Republic) by observing 114 cases of personal bankruptcy. 


\section{Sampling}

The research includes all allowed debt relief of individuals who applied for personal bankruptcy in the time period between 1.1.2008 and 31.12.2011 and whose process of personal bankruptcy has been declared as successfully completed until the first quarter of $2015 .^{4}$ For the needs of research, all individuals were divided according to age structure. The primary sources of data are detailed information published in Insolvency Register. The significant defect of this source was the fact that all documents are stored in pdf format and therefore it was very challenging to get necessary data. (Department of Justice, Czech Republic, Insolvency Register, 2015)

The sample of finished personal bankruptcies - natural persons who have gone through the process of debt relief, includes debtors who:

- fulfilled the debt relief via repayment plan within 5 years

- fulfilled the debt relief via repayment plan and they paid $100 \%$ of signed claims of creditors within 5 years

- fulfilled the debt relief via selling debtors assets.

\section{Sample distribution}

From the primary database stored in the Insolvency Register we found out that the final number of examined insolvency process was 1.352 from the total amount of 8.538 of accepted debt relieves. Other processes are still ongoing and they are expected to be finished during the years 2015 and 2016 (see Tab.1).

Table 1 Accepted debt relieves

\begin{tabular}{|c|c|c|}
\hline $\begin{array}{c}\text { Accepted debt relieves in CR } \\
\text { between } \\
\text { 1. 1. } 2008 \text { and 31. 12.2011 }\end{array}$ & $\begin{array}{l}\text { Debt relieves completed } \\
\text { until } \\
\text { the first quarter of } 2015\end{array}$ & $\begin{array}{c}\text { Ongoing debt relieves } \\
\text { accepted between }\end{array}$ \\
\hline 8538 & 1352 & 7186 \\
\hline
\end{tabular}

(Source: Based on own research of authors, 2016)

The primary sample of finished personal bankruptcies for the further research was 1352 individuals. Then the sample of debtors was divided into four categories according to their age:

- from 18 until 29 years,

- from 30 until 44 years,

- from 45 until 54 years,

- 55 years and more.

Another division concerned sources of debtor's income:

- employment,

- old age pension

- full disability pension,

- partial disability pension,

\footnotetext{
${ }^{4}$ The collection of data for this research was conducted by Ing. Kateřina Smejkalová.
} 
- combination of employment and old age pension,

- combination of employment and full disability pension,

- combination of employment and partial disability pension,

- combination of employment and widow's pension,

- combination of old age pension and widow's pension,

- others,

- not identified.

The last division of debtors sample was according to their net income:

- less than $10000 \mathrm{CZK}$,

- $10000 \mathrm{CZK}-12999 \mathrm{CZK}$,

- $13000 \mathrm{CZK}-14999 \mathrm{CZK}$,

- $15000 \mathrm{CZK}-19999 \mathrm{CZK}$,

- $20000 \mathrm{CZK}$ and more.

The main sample of all completed personal bankruptcies was also researched from the perspective:

- The overall amount of reported debt by the debtors in each year,

- The type of debt reported by the debtors in different age categories (age structure),

- The overall amount of registered financial claims.

At the end of the research the amount of registered financial claims was compared with the rate of satisfaction based on results of fulfilled debt reliefs. For this purpose were created ranges of percentage satisfaction of creditors:

- $100 \%$,

- $60.00 \%-99.99 \%$,

- $50.00 \%-59.99 \%$,

- $35.00 \%-49.99 \%$,

- $30.00 \%-34.99 \%$,

- less than $30 \%$.

\section{RESULTS OF RESEARCH}

Results of the research are summarized in following tables $2,3,4,5,6,7,8,9$ and 10.

Table 2 Division of personal bankruptcies of debtors according to their age and source of income

\begin{tabular}{|c|c|c|c|c|c|}
\hline \multirow[t]{2}{*}{ Sources of income of debtors } & \multicolumn{4}{|c|}{$\begin{array}{c}\text { Age structure of debtors from finished debt } \\
\text { relieves }\end{array}$} & \multirow[t]{2}{*}{ Total } \\
\hline & $18-29$ & $30-44$ & $45-54$ & $55+$ & \\
\hline Employment & 193 & 538 & 262 & 94 & 1087 \\
\hline Old age pension & 0 & 0 & 2 & 59 & 61 \\
\hline Full disabled pension & 1 & 14 & 14 & 23 & 52 \\
\hline Partial disabled pension & 0 & 6 & 3 & 1 & 10 \\
\hline
\end{tabular}




\begin{tabular}{|l|c|c|c|c|c|}
\hline $\begin{array}{l}\text { Combination of employment and } \\
\text { old age pension }\end{array}$ & 0 & 0 & 0 & 23 & 23 \\
\hline $\begin{array}{l}\text { Combination of employment and } \\
\text { full disabled pension }\end{array}$ & 0 & 3 & 2 & 4 & 9 \\
\hline $\begin{array}{l}\text { Combination of employment and } \\
\text { partial disabled pension }\end{array}$ & 5 & 19 & 24 & 24 & 72 \\
\hline $\begin{array}{l}\text { Combination of employment and } \\
\text { widow's pension }\end{array}$ & 0 & 5 & 2 & 1 & 8 \\
\hline $\begin{array}{l}\text { Combination of old age pension } \\
\text { and widow's pension }\end{array}$ & 0 & 1 & 2 & 19 & 22 \\
\hline Others & 0 & 0 & 1 & 2 & 3 \\
\hline Not identified & 0 & 2 & 3 & 0 & 5 \\
\hline Total & $\mathbf{1 9 9}$ & $\mathbf{5 8 8}$ & $\mathbf{3 1 5}$ & $\mathbf{2 5 0}$ & $\mathbf{1 3 5 2}$ \\
\hline
\end{tabular}

(Source: Based on own research of authors, 2016)

Based on examining, it was found that predominant source of income, which will be used in most of the cases to repay creditors through the repayment schedule and satisfied them, is debtor's wage regardless of his age. At the same time, it is logical that since the age group 45-54 and 55+, the share of other sources of income is gradually increasing in comparison with debtor's wage. As people get older, it comes with a variety of health issues and complications which prevent the debtor from working at full power. Therefore there are more often represented other sources of income in these age groups, especially different types of pensions and other payments from the state. 
Table. 3 Distribution of personal bankruptcies of debtors according to their monthly net income

\begin{tabular}{|l|c|c|}
\hline \multicolumn{1}{|c|}{$\begin{array}{c}\text { Monthly } \\
\text { net income in CZK }\end{array}$} & $\begin{array}{c}\text { Amount of completed } \\
\text { personal bankruptcies } \\
\text { (abs.) }\end{array}$ & $\begin{array}{c}\text { Amount of completed } \\
\text { personal bankruptcies } \\
(\%)\end{array}$ \\
\hline Less than 10000 & 100 & $7.4 \%$ \\
\hline $\mathbf{1 0 0 0 0}-\mathbf{1 2} \mathbf{9 9 9}$ & $\mathbf{3 0 9}$ & $\mathbf{2 2 . 8 \%}$ \\
\hline $13000-14999$ & 185 & $13.7 \%$ \\
\hline $\mathbf{1 5 0 0 0}-\mathbf{1 9 9 9 9} \mathbf{0 9 9}$ & $\mathbf{4 1 7}$ & $\mathbf{3 0 . 8 \%}$ \\
\hline $\mathbf{2 0 0 0 0}$ and more & $\mathbf{3 2 9}$ & $\mathbf{2 4 . 4 \%}$ \\
\hline $\begin{array}{l}\text { Debtors who cannot be } \\
\text { assigned to any of observed } \\
\text { group }\end{array}$ & 12 & $0.9 \%$ \\
\hline $\begin{array}{l}\text { Total amount of completed } \\
\text { personal bankruptcies }\end{array}$ & $\mathbf{1 3 5 2}$ & $\mathbf{1 0 0 . 0 \%}$ \\
\hline
\end{tabular}

(Source: Based on own research of authors, 2016)

Besides, debtors source of income, the aim was also to find out their monthly net income. The processing of this issue was based on information, which was presented by debtors themselves in their insolvency proposal. There were twelve debtors who could not be assigned to any of observed income group due to undergoing the personal bankruptcy through monetizatizing of their assets. Therefore the results of research would have been distored if taken into account. On the basis of summarizing data was found that the largest group are debtors with monthly net income in between of $15000 \mathrm{CZK}$ and $19999 \mathrm{CZK}$, second largest group are debtors with income over $20000 \mathrm{CZK}$. At the third position are debtors with income between $10000 \mathrm{CZK}$ and $12999 \mathrm{CZK}$. Moreover the table 3 shows that group of debtors whose income is less than $10000 \mathrm{CZK}$, participates in the research sample by $7.4 \%$. It is astonishing that creditors were willing to provide funding to such a group of debtors. At first glance, it is obvious that these debtors must have issues with the payment for basic living needs. So money they borrow are most likely used just for consumption with unrealistic view of payback.

Table 4 shows the total amount of reported debt by the debtors in each year. The research demonstrated that the average of total debt reported by a single debtor ranged between 456000 CZK and $676000 \mathrm{CZK}$.

Table. 4 Total amount of reported debt by the debtors in the Czech Republic between 2008 and 2011

Year

Total Amount of reported debt by the debtors (CZK) 


\begin{tabular}{|c|c|}
\hline 2008 & 127938492 \\
\hline 2009 & $315439804^{*}$ \\
\hline 2010 & 150591491 \\
\hline 2011 & 173967039 \\
\hline Total & $\mathbf{7 6 7 9 3 6 ~ 8 2 6}$ \\
\hline
\end{tabular}

(Source: Based on own research of authors, 2016)

*In the year 2009 was the total amount of registered financial claims the highest because during that year was approved the most of the insolvency proposals within the researched sample.

Table 5 Structure of the debt reported by the debtors according to the different age groups

\begin{tabular}{|l|c|c|c|c|}
\hline \multirow{2}{*}{ Type of debt } & \multicolumn{5}{|c|}{$\begin{array}{c}\text { Age groups and the structure of reported debts by debtors } \\
\text { (in mil. CZK) }\end{array}$} \\
\cline { 2 - 5 } & $18-29$ & $30-44$ & $45-54$ & $55+$ \\
\hline loans & $\mathbf{7 5 . 3}$ & $\mathbf{2 8 2 . 8}$ & $\mathbf{1 6 1 . 3}$ & $\mathbf{1 0 9 . 4}$ \\
\hline insurance & 0.9 & 1.4 & 0.9 & 0.3 \\
\hline mobile operators & 1.0 & 3.3 & 1.2 & 0.7 \\
\hline alimony & 0.0 & 0.3 & 0.0 & 0.0 \\
\hline other & 13.8 & 64.1 & 29.5 & 21.7 \\
\hline Total & $\mathbf{9 1 . 0}$ & $\mathbf{3 5 1 . 9}$ & $\mathbf{1 9 2 . 9}$ & $\mathbf{1 3 2 . 1}$ \\
\hline
\end{tabular}

(Source: Based on own research of authors, 2016)

Table. 6 Share of different types of debts on the total debts reported by the debtors in the Czech Republic between 2008 and 2011

\begin{tabular}{|l|c|c|}
\hline Type of debts & $\begin{array}{c}\text { Reported debts by the debtors } \\
\text { in mil. CZK } \\
(\text { abs. })\end{array}$ & $\begin{array}{c}\text { Reported debts by the debtors } \\
(\%)\end{array}$ \\
\hline loans & $\mathbf{6 2 8 . 8}$ & $\mathbf{8 1 . 8 9 \%}$ \\
\hline insurance & 3.5 & $0.45 \%$ \\
\hline mobile operators & 6.2 & $0.81 \%$ \\
\hline alimony & 0.3 & $0.04 \%$ \\
\hline other & 129.1 & $16.81 \%$ \\
\hline Total & $\mathbf{7 6 7 . 9}$ & $\mathbf{1 0 0 . 0 0 \%}$ \\
\hline
\end{tabular}

(Source: Based on own research of authors, 2016) 
Tables 5 and 6 demonstrate that the loans (bank and non-bank) are the most common type of debt throughout all age groups. The last group 'other' includes (e.g.) unpaid tenancy, unpaid home energy consumption (electricity, gas etc.), loans from the third parties (friends, family - noninstitutionalised lenders). Overall the most indebted age group was represented by the citizens between 30 and 44 years.

The research also demonstrates the difference between the total amount of reported debt by the debtors (table 4) and the total amount of registered financial claims (see table 7). Nonetheless, it is important to realize that the total amount of registered financial claims represents only those claims that were acknowledged by the government authorities. E.g., debtor has reported total debts of 500 thousands CZK, but total amount of registered financial claims by creditors is only 450 thousands CZK. Therefore the rate of satisfied creditors is higher if taken into account only the registered financial claims.

\section{Table 7 Total Amount of Registered Financial Claims against the Debtors in the Czech Republic between 2008 and 2011}

\begin{tabular}{|c|c|}
\hline Year & Total Amount of Registered Financial Claims (CZK) \\
\hline 2008 & 127091590 \\
\hline 2009 & $307921503^{*}$ \\
\hline 2010 & 127908294 \\
\hline 2011 & 135049458 \\
\hline Total & $\mathbf{6 9 7 9 7 0 ~ 8 4 5}$ \\
\hline
\end{tabular}

(Source: Based on own research of authors, 2016)

*In the year 2009 was the total amount of registered financial claims the highest because during that year was approved the most of the insolvency proposals within the researched sample.

\section{Table 8 The difference between the total debt reported by debtors and the overall acknowledged financial claims in the Czech Republic between 2008 and 2011}

\begin{tabular}{|c|c|c|}
\hline Year & $\begin{array}{c}\text { Unregistered /unacknowledged } \\
\text { claims in relation to reported debt } \\
\text { by the debtors } \\
(\text { abs. })\end{array}$ & $\begin{array}{c}\text { Unregistered /unacknowledged } \\
\text { claims in relation to reported debt } \\
\text { by the debtors } \\
\text { (\%) }\end{array}$ \\
\hline 2008 & 846902 & $0.66 \%$ \\
\hline 2009 & 7518301 & $2.38 \%$ \\
\hline 2010 & 22683197 & $17.73 \%$ \\
\hline 2011 & 38917581 & $22.37 \%$ \\
\hline Total & $\mathbf{6 9 9 6 5 9 8 1}$ & $\mathbf{9 . 1 1 \%}$ \\
\hline
\end{tabular}

(Source: Based on own research of authors, 2016) 
Table 8 demonstrate that the overall difference between the total amount of reported debt by the debtors and the total amount of registered financial claims (from 2008 to 2011) was 69965981 CZK. This was generally caused by two factors. Either creditors did not register their financial claims or government authorities rejected creditors' claims. It is important to realize that during the insolvency procedure only those claims that were properly registered and acknowledged by the government authorities are being satisfied.

Table 9 Number of personal bankruptcies in relation to the degree of satisfaction of creditors in the Czech Republic

\begin{tabular}{|l|c|c|}
\hline $\begin{array}{l}\text { Percentage ranges of satisfied } \\
\text { creditors from completed personal } \\
\text { bankruptcies }\end{array}$ & $\begin{array}{l}\text { Number of personal } \\
\text { bankruptcies in relation } \\
\text { to the degree of } \\
\text { satisfaction of creditors }\end{array}$ & $\begin{array}{l}\text { Share of each group in total } \\
\text { examined sample }\end{array}$ \\
\hline $\mathbf{1 0 0} \%$ & $\mathbf{7 1 1}$ & $\mathbf{5 2 . 6}$ \\
\hline $60.00-99.99 \%$ & 134 & 9.9 \\
\hline $50.00-59.99 \%$ & 78 & 5.8 \\
\hline $35.00-49.99 \%$ & 206 & 15.2 \\
\hline $30.00-34.99 \%$. & 192 & 14.2 \\
\hline Less than $\mathbf{3 0} \%$ & $\mathbf{3 1}$ & $\mathbf{2 . 3}$ \\
\hline Total & $\mathbf{1 3 5 2}$ & $\mathbf{1 0 0 . 0}$ \\
\hline
\end{tabular}

(Source: Based on own research of authors, 2016)

Table 10 Number of personal bankruptcies in relation to the degree of satisfaction of the creditors and debtors age in the Czech Republic

\begin{tabular}{|c|c|c|c|c|c|}
\hline \multirow{2}{*}{$\begin{array}{l}\text { Percentage ranges of satisfied } \\
\text { creditors from completed personal } \\
\text { bankruptcies }\end{array}$} & \multicolumn{4}{|c|}{$\begin{array}{c}\text { Age structure of debtors from completed } \\
\text { personal bankruptcies }\end{array}$} & \multirow{2}{*}{ Total } \\
\hline & $18-29$ & $30-44$ & $45-54$ & $55+$ & \\
\hline $100 \%$ & 133 & 295 & 158 & 125 & 711 \\
\hline $60,00-99,99 \%$ & 16 & 57 & 37 & 24 & 134 \\
\hline $50,00-59,99 \%$ & 6 & 41 & 18 & 13 & 78 \\
\hline $35,00-49,99 \%$ & 17 & 94 & 48 & 47 & 206 \\
\hline $30,00-34,99 \%$ & 25 & 88 & 46 & 33 & 192 \\
\hline less than $30 \%$ & 2 & 13 & 8 & 8 & 31 \\
\hline Total & 199 & 588 & 315 & 250 & 1352 \\
\hline
\end{tabular}

(Source: Based on own research of authors, 2016)

The table 7, 9 and 10 shows that total of 711 debtors (52.6\%) across all age categories has fulfilled all their obligations to their creditors. The largest age group is formed by debtors in age between 30 and 44. In this context it is necessary to draw attention to the fact that in the course of insolvency 
proceedings are satisfied only creditor claims which are submitted to the insolvency proceedings. If any of the creditors have not sign in his claim in due time, he will not be satisfied during the process of debt relief and this debt will not be taken into account at all.

In addition, it is necessary to mention that 31 debtors failed to achieve the minimum threshold of creditor satisfaction which according to the law is $30 \%$ out of all signed claims. However, this situation may occur in the course of debt relief. E.g. debtor in the course of debt relief lost a job for a certain period and therefore could not pay his debts as intensely as before. If there is no intention to avoid finding a new job, there is no reason to terminate the process of debt relief. When debt relief is being approved, the $30 \%$ threshold must be fulfilled, but is always based on the past. The current level of net income can be higher or lower, but it is always fundamental for the course of debt relief to have regular income and not to violate the conditions laid down.

\section{DISCUSSION}

The Insolvency Act is for those who seek help in a moment of realizing their situation is not sustainable anymore. Situation is not sustainable when the debt is growing even though debtor paid all repayments it could have, therefore the total debt is not decreasing but on the contrary still increasing. But what precedes this situation? How can anyone end up in a situation like this? There are two main factors. First, the financial literacy of the population is on a very low level and they are not always capable to evaluate all aspects related to their commitments. Problem of calculating all expected expenditure, as interest and fees, connected with the commitment is really common among the population and sometimes even those who provide financial services have troubles doing so. Which leads to the second factor and that is quality of financial services provider. The problem is not just whether they are experts and are able to calculate correctly expected expenditure for a client, but also the ethical and moral view. Whether they provide honest service without misleading client expectations of future obligation.

Even though The Insolvency Act helps those who need a second chance, there must be an improvement in financial literacy among people, which could be achieved by including basis of financial literacy into schools and also involve companies and employers to organize financial literacy workshops and seminars for their employees on a regular basis. That would help to avoid the personal bankruptcy in a first place. There should be also more emphasis on professional, ethical and moral qualities of those who provides financial services.

\section{CONCLUSION}

Out of 1.352 examined debtors 711 have paid $100 \%$ of their creditor claims which represents $52.6 \%$. Such results are very surprising as more than a half of debtors from our researched sample (who at one point in time found themselves in the situation where they declared a personal bankruptcy) managed to repay 100\% of their debts. Second largest group of 206 debtors satisfied between $35 \%$ and $49.99 \%$ of their creditor claims in the course of debt relief.

From our sample of 1.352 debtors, $97.7 \%$ (1 321 debtors) repaid at least $30 \%$ of their debts - this represents the minimal boundary $(30 \%)$ which allows the institution of personal bankruptcy to be applied. However, 31 debtors $(2.3 \%)$ still did not manage to repay at least the necessary $30 \%$ of their debts. Nevertheless, the process of personal bankruptcy still successfully occurred and these debtors were forgiven the rest of their debts. This was caused by the fact that for the process of personal bankruptcy to begin the debtors must be able to pay in the five-year period at least the 
aforementioned $30 \%$ of their debts. Additionally, during this five-year period the debtor is obliged to make a continuous effort to repay back to its creditors as much as possible. Nevertheless, during the five-year period the debtor might go through the unexpected circumstances (such as a long-term illness, losing his/her job etc.) which could prevent him/her from paying at least the aforementioned $30 \%$ of debts - in such case the debtor's debts might still be forgiven.

Simplified structure of persons in debt relief according to social standing from the perspective of income source can be divided into three groups - employee, pensioner, working pensioner, where $80 \%$ of debtors are in an employment relationship. The results corresponds with similar results of research conducted by Paseková \& Bařinová (2013).

Out of all aforementioned types of debts - loans (bank and non-bank) are not just the most common type of debt which is represented throughout all age groups, but are also the most common type of debt causing insolvency process to begin. Moreover, based on this research it was demonstrated that the majority of debtors who applied for the process of personal bankruptcy have more than one of such loans.

Overall, the institution of personal bankruptcy represents an alternative for solving a situation of an indebted citizen of the Czech Republic. In case that the debtor fulfil the repayment schedule and live on the living wage for up to 60 months, he has the opportunity to apply for the debt relief from yet unpaid portion of debt by the end of the 60 months (five-year period). However, in case that the indebted citizen would not apply (or could not apply) for the personal bankruptcy process, the indebted citizen (debtor) would face the risk of execution on his/her property. Additionally, in such case no debts could be forgiven. (Hásová, 2012)

\section{ACKNOWLEDGMENT}

Monika Randáková: The article is one of the research outputs of Institutional Support for LongTerm Strategic Development of Research, Development and Innovation at the Faculty of Finance and Accounting, University of Economics Prague in 2016.

\section{REFERENCES}

[1] Agrawal, S. et al., Consumer bankruptcy and default: The role of individual social capital, Journal of Economic Psychology, Vol. 32, No. 4, 2010, pp. 632-650.

[2] Bonaci, C., G. \& Strouhal, J., Corporate governance lessons and traders'dilemma enhanced by the financial crisis. In A. Zemliak, N. Mastorakis (Eds.), $5^{\text {th }}$ WSEAS International Conference on Business Administration, 2011, pp. 66-69.

[3] Carter, R. \& Van Auken, H., Small firm bankruptcy, Journal of Small Business Management, Vol. 44, No. 3, 2006, pp. 493-512.

[4] Department of Justice, Insolvency Register [online], available from: http://www.or.justice.cz. (2015-04-15).

[5] Di Martino, P., Approaching disaster: Personal bankruptcy legislative in Italy and England, Business History, Vol. 47, No. 1, 2005, pp. 23-43.

[6] Hásová, J. \& Moravec, T., Insolvency Proceedings, Praha. C. H. Beck, 2013.

[7] Hásová, J., The relationship of execution and insolvency proceedings, Komorni listy, Vol. 4, No. 1, 2012, pp. 13-20. 
[8] Korol, T. \& Korodi, A. Predicting bankruptcy with the use of macroeconomic variables. Economic computation and economic cybernetics studies and research, 2010. 44 (1), 201-219. DOI: $10.1007 / \mathrm{s} 11134-011-9647-2$

[9] Maršíková, J., Insolvency Act: with notes, case law, Council Regulation (EC) 1346/2000 and implementing regulations, Praha Leges, 2014.

[10]Paseková, M. \& Bařinová, D., An analysis of the incidence of personal bankruptcy in the Moravian-Silesian region in the Czech Republic, In E. Jirickova, E. Knapkova, E. Pastuszkova (Eds.), Proceedings of the $6^{\text {th }}$ International Scientific Conference Finance and the Performance of Firms in Science, Education, and Practice, 2013, pp. 547-559.

[11] Resolution of the High Court in Prague of 11. 5. 2010, Sp. zn. KSPH 30 InS 2561/2010, 1VSPH 280/2010-A.

[12] Savu, A. The intersection of health and wealth: association between personal bankruptcy and myocardial infarction rates in Canada, 2016. In BMC Public Health. Vol 15, ISSN: 1471-2458. DOI: 10.1186/s12889-016-2705-X.

[13] Smrčka, L., The relation between indebtedness of the government, public sector and households in the Czech Republic. In E. Jirickova, E. Pastuszkova, J. Svoboda (Eds.), $5^{\text {th }}$ International Scientific Conference on Finance and the Performance of Firms in Science, Education and Practice, 2011, pp. 433-446.

[14] Strouhal, J. et al., Financial instruments and fair value: accounting obstacles for the worldwide globalization project? In E. Jirickova, E. Pastuszkova, J. Svoboda (Eds.), $5^{\text {th }}$ International Scientific Conference on Finance and the Performance of Firms in Science, Education and Practice, 2011, pp. 458-468.

[15] Stumm, S. et al., Financial capability, money attitudes and socioeconomic status: Risks for experiencing adverse financial events, Personality and Individual Differences, Vol. 54, No. 3, 2012, pp. 344-349.

[16] Tučková, Z. \& Strouhal, J., On management of knowledge services. In L. Zadeh, N. Mastorakis (Eds.), $9^{\text {th }}$ WSEAS International Conference on Artificial Intelligence, Knowledge Engineering and Databases, 2010, pp. 327-332.

[17]Xiong, T. Personal bankruptcy prediction by mining credit card data. In Expert systems with applications, 2013 (pp. 665-676). Vol. 30. ISSN: 0957-4174. DOI: 10.1016/j.eswa.2012.07.072 